\title{
Two Late Quaternary Pollen Records from South-Central
} Alaska

\section{Deux inventaires polliniques du Quaternaire supérieur en provenance du centre-sud de l'Alaska \\ Две позднецетвертицные пыдыцевые записи иэ южных районв Центральльной Аляски}

\author{
P. M. Anderson, A. V. Lozhkin, W. R. Eisner, M. V. Kozhevnikova, D. M. Hopkins, \\ L. B. Brubaker et P. A. Colinvaux
}

Volume 48, numéro 2, 1994

URI : https://id.erudit.org/iderudit/032990ar

DOI : https://doi.org/10.7202/032990ar

\section{Aller au sommaire du numéro}

\section{Éditeur(s)}

Les Presses de l'Université de Montréal

\section{ISSN}

0705-7199 (imprimé)

1492-143X (numérique)

\section{Découvrir la revue}

Citer cet article

Anderson, P. M., Lozhkin, A. V., Eisner, W. R., Kozhevnikova, M. V., Hopkins, D. M., Brubaker, L. B. \& Colinvaux, P. A. (1994). Two Late Quaternary Pollen Records from South-Central Alaska. Géographie physique et Quaternaire, 48(2), 131-143. https://doi.org/10.7202/032990ar

\section{Résumé de l'article}

Les inventaires polliniques de Wonder Lake et de Ten Mile Lake, situés à la limite altitudinale des arbres au nord et au sud de la chaîne de l'Alaska permettent de reconstituer l'histoire de la végétation d'une portion de la forêt boréale du sud de l'Alaska. Les nouveaux diagrammes polliniques montrent une toundra arbustive à Betula, précédée au Wonder Lake par une toundra herbacée clairsemée, à la fin du Wisconsinien. Vers 10000 BP, Populus était dans les environs du Ten Mile Lake, mais était apparamment absent du Wonder Lake. Picea glauca croissait autour du Ten Mile Lake à $9100 \mathrm{BP}$ et P. mariana prenait de l'importance vers $7000 \mathrm{BP}$. Au Wonder Lake, les premières forêts ont également été dominées par P. glauca, puis par un nombre croissant de P. mariana. La chronologie de !'afforestation est incertaine en raison de datations au radiocarbone douteuses. Alnus semble être une espèce courante dans les deux régions vers $7000 \mathrm{BP}$. Les inventaires indiquent que la reconstitution de la paléovégétation est plus difficile à faire pour les forêts méridionales que septentrionales de l'Alaska, en raison de la plus grande diversité topographique, la sur-représentation de certains taxons et des problèmes de radio-datation. Les données indiquent tout de même que l'histoire de la végétation des forêts diffèrent au nord et au sud. Ces différences, mises en relation avec les fluctuations de températures présumées de l'Holocène, laissent croire que la forêt de l'Alaska ne répondra pas nécessairement de façon uniforme à un réchauffement climatique éventuel.
Tous droits réservés @ Les Presses de l'Université de Montréal, 1994
Ce document est protégé par la loi sur le droit d'auteur. L'utilisation des services d’Érudit (y compris la reproduction) est assujettie à sa politique d'utilisation que vous pouvez consulter en ligne.

https://apropos.erudit.org/fr/usagers/politique-dutilisation/ 


\title{
TWO LATE QUATERNARY POLLEN RECORDS FROM SOUTH-CENTRAL ALASKA*
}

\begin{abstract}
P.M. ANDERSON ${ }^{1}$, A.V. LOZHKIN ${ }^{2}$, W.R. EISNER ${ }^{3}$, M.V. KOZHEVNIKOVA ${ }^{2}$, D.M. HOPKINS ${ }^{4}$, L.B. BRUBAKER ${ }^{5}$ and P.A. COLINVAUX ${ }^{6}$ : ' Quaternary Research Center AK-60, University of Washington, Seattle, Washington 98195, U.S.A.; ${ }^{2}$ NorthEast Interdisciplinary Research Institute, Far Eastern Branch, Russian Academy of Science, 16 Portovaya Street, Magadan 685000, Russia; ${ }^{3}$ Byrd Polar Research Center, The Ohio State University, Columbus, Ohio 43210, U.S.A.; ${ }^{4}$ Alaska Quaternary Center, 906 Yukon Drive, University of Alaska, Fairbanks, Alaska 99775, U.S.A..; ${ }^{5}$ College of Forest Resources, University of Washington AR-10, Seattle, Washington 98195, U.S.A.; ${ }^{6}$ Smithsonian Tropical Research Institute, APO, Miami, Florida 34002, U.S.A.
\end{abstract}

ABSTRACT Pollen records from Wonder and Ten Mile lakes, located at altitudinal treeline to the north and south of the Alaska Range respectively, document the vegetation history of a portion of the southern Alaskan boreal forest. The new pollen diagrams indicate a Betula shrub tundra, preceded at Wonder Lake by a sparse herb tundra, which characterized these two areas during latest Wisconsinan times. Populus was in the vicinity of Ten Mile Lake ca. $10,000 \mathrm{BP}$, but was apparently absent from Wonder Lake. Picea glauca grew at or near Ten Mile Lake by $9100 \mathrm{BP}$, with $P$. mariana becoming important ca. $7000 \mathrm{BP}$. The first forests at Wonder Lake were also dominated by $P$. glauca and followed by increased numbers of $P$. mariana. The timing of forest establishment at Wonder Lake is uncertain due to problematic radiocarbon dates. Alnus appears to be common in both regions by $c a$. 7000 BP. These records suggest that paleovegetational reconstructions are more difficult for the southern than northern boreal forests in Alaska because of greater topographic diversity, difficulties with overrepresentation of some pollen taxa, and problems with radiocarbon dating. Despite these concerns, available data from southcentral Alaska suggest that southern and northern forests differ in their vegetational histories. Such differences, when related to temperature fluctuations that have been postulated for the Holocene, imply that the Alaskan boreal forest may not respond uniformly to future global warming.
RÉSUMÉ Deux inventaires polliniques du Quaternaire supérieur en provenance du centre-sud de l'Alaska. Les inventaires polliniques de Wonder Lake et de Ten Mile Lake, situés à la limite altitudinale des arbres au nord et au sud de la chaîne de l'Alaska permettent de reconstituer l'histoire de la végétation d'une portion de la forêt boréale du sud de l'Alaska. Les nouveaux diagrammes polliniques montrent une toundra arbustive à Betula, précédée au Wonder Lake par une toundra herbacée clairsemée, à la fin du Wisconsinien. Vers 10000 BP, Populus était dans les environs du Ten Mile Lake, mais était apparamment absent du Wonder Lake. Picea glauca croissait autour du Ten Mile Lake à $9100 \mathrm{BP}$ et $P$. mariana prenait de l'importance vers $7000 \mathrm{BP}$. Au Wonder Lake, les premières forêts ont également été dominées par $P$. glauca, puis par un nombre croissant de $P$. mariana. La chronologie de l'afforestation est incertaine en raison de datations au radiocarbone douteuses. Alnus semble être une espèce courante dans les deux régions vers $7000 \mathrm{BP}$. Les inventaires indiquent que la reconstitution de la paléovégétation est plus difficile à faire pour les forêts méridionales que septentrionales de l'Alaska, en raison de la plus grande diversité topographique, la sur-représentation de certains taxons et des problèmes de radiodatation. Les données indiquent tout de même que l'histoire de la végétation des forêts diffèrent au nord et au sud. Ces différences, mises en relation avec les fluctuations de températures présumées de l'Holocène, laissent croire que la forêt de l'Alaska ne répondra pas nécessairement de facon uniforme à un réchauffement climatique éventuel.
РЕЗЮМЕ Две позднечетвертичные пыдьцевые записи из южных районов Центральльной Аляски. Пыльцевые диаграммы осадков озер Ваеде и Тенмайл, расположенных вблизи верхней границы леса на севере и юrе Аляскинского хребта, отражают историю растительности южной части бореального леса Аляски. Новые пыльцеье диаграммы показывают, что кустарниковой бергзовой тундре, характерной для зтих двух территорий в течение позднего висконсина, предшествовада в отдожениях оз. Ванде бедная травянистяа тундра. Populus прорпзрагтал в окрестностях оз. Тенмайл 10000 л.н., но, ло-видимому, отсутствовад в районе оз. Ванае. 9100 л.н. в районе оз. Тенмайл или в непосредственной близости от него произрастала Picea glauca, которая вмерте с Picea mariana играет значительную роль в составе растительности около 7000 л.н. В первых лесах в районе оз. Ванде также доминировала Picea glauca, но затем роль Picea mariana начинает возрасастать. Время появления лесов в районе оз. Ванде иокане устанавливается надежно радиоуглеродным методом. Alnus образует сообщества в обоих районах около 7000 л.н. Полученные данные свидетельствуют о том, что реконструкция растительности будет более сложной для южных, чем для северных бореальных лесов Аляски из-за значительного топографического несходства, затруднения в интерпретации некоторых пыльцевых таксонов, проблем с радиоуглеродным датирванием. Несмотря на зти проблемы, полфченные данные показыают, что бореальные леса на юге и севере южной части Центальной Аляски имеют разлчную историю. Такие различия, связханные с измененлями землератур в теченле голоцена, свидетельствуют, что бореальный лес Аляски может не отвечать сченарию глобального потепления в будущем.

\footnotetext{
Manuscrit reçu le 15 juin 1993; manuscrit révisé accepté le 6 décembre 1993

* PALE Contribution No. 11
} 


\section{INTRODUCTION}

Palynologists often focus on the history of late Quaternary vegetation boundaries to improve the understanding of plantclimate interactions, since such ecotones are particularly sensitive to environmental change caused by variations in temperature and effective moisture. The record of the northern Alaskan boreal forest, representing the ecotone between the boreal forest and tundra, is well documented (Anderson and Brubaker, 1993; Lamb and Edwards, 1988; Ager and Brubaker, 1985) and indicates that the development of the modern forest was strongly affected by variations in seasonal insolation (Barnosky et al., 1987). However, the response of the southern boreal forest to postglacial climatic fluctuations is poorly known (Ager and Brubaker, 1985; Ager, 1983). The probability that subarctic environments will change profoundly due to increased levels of anthropogenic gases makes such information vital for evaluating the possible effects of climatic change on boreal ecosystems (Schlesinger and Mitchell, 1987; Pastor and Post, 1988, Emanuel et al., 1985).

Paleovegetational interpretations for the southern Alaskan boreal forest are limited, because the published pollen records are poorly dated and are from widely scattered localities (Ager, 1983; Ager and Brubaker, 1985). To improve these interpretations, it will be necessary to both sample sites in areas where the vegetation history is unknown and sites near previously sampled lakes so that the trends in the published pollen records can be verified. Pollen and macrofossil records from Eightmile and Tangle Lakes (Ager, 1983; Ager and Sims, 1981; Schweger, 1981) currently provide the only published information about the Holocene-late Pleistocene vegetation of the Alaska Range, the major geographic feature of south-central Alaska (i.e., the region between the northern foothills of the Alaska Range and the northern coast of the Gulf of Alaska). To confirm the vegetational histories from these two key Alaska Range sites, we recovered sediments from Ten Mile and Wonder Lakes, located in the altitudinal forest-tundra ecotone of the Gulkana Uplands and northern Alaska Range, respectively (Figs. 1 and 2A). Comparison of the Ten Mile and Wonder results to sites from the Alaska Range and other parts of south-central Alaska (Table I), while far from definitive, do suggest regional differences in the development of the southern and northern boreal forest.

\section{THE SITES}

\section{TEN MILE LAKE}

Ten Mile Lake (informal name; $63^{\circ} 04^{\prime} \mathrm{N} 145^{\circ} 42^{\prime} \mathrm{W}$; $1000 \mathrm{~m}$ ) lies on the southeastern edge of the Gulkana Uplands in a broad trough confined by mountains of $\mathrm{ca}$. $1400 \mathrm{~m}$ summits. Approximately $20 \mathrm{~km}$ to the north, the towering peaks of the heavily glaciated eastern Alaska Range rise to altitudes of $4000 \mathrm{~m}$. Today the lake is part of a complex drainage flowing into the Gulkana River (Fig. 2B). Ten Mile Lake contains two basins of $14 \mathrm{~m}$ and $6 \mathrm{~m}$ depth. Although both basins were sampled, we chose to analyze the core from the shallower one, because its sedimentology suggested a more complete postglacial record.
Altitudinal treeline (ca. $900 \mathrm{~m}$ ), comprised of Picea glauca, occurs ca. $5 \mathrm{~km}$ to the east of Ten Mile Lake with the main body of the forest, dominated by Picea mariana, occupying the nearby Delta and Copper River valleys (Fig. 2A). Betula glandulosa and Salix spp. dominate the shrub tundra surrounding the lake, but a variety of ericaceous species (e.g., Vaccinium uliginosum, Ledum decumbens, Vaccinium vitisidaea, Empetrum nigrum) are common locally. Graminoids and lichens are typical in less favorable sites.

Ten Mile Lake lies well within the limits of former large, piedmont ice tongues of Late Wisconsinan age (Donnelly or Denali II glaciation of Péwé, 1975; Péwé and Reger, 1975) that spread southward from the Alaska Range (Fig. 2B). Several hundred meters of glacial ice likely covered the site, as attested to by the southwest-oriented roches moutonnées (glacier-scoured streamlined hillocks) on the adjoining mountain sides and ribbed moraines in the immediate vicinity of the lake. A series of dry gorges crossing the northern crest of Paxson Mountain indicates a history of slow downwasting of this ice cover.

Though Ten Mile Lake presently drains to the south, an esker complex surrounding the lake records a former northward subglacial drainage. An outwash train leading toward the Delta River shows that this northward drainage persisted for at least a short time after the glacial ice disappeared. Ten Mile Lake, itself, was confined when tilting caused by postglacial isostatic recovery shifted the drainage divide ca. $6.5 \mathrm{~km}$ to the north.

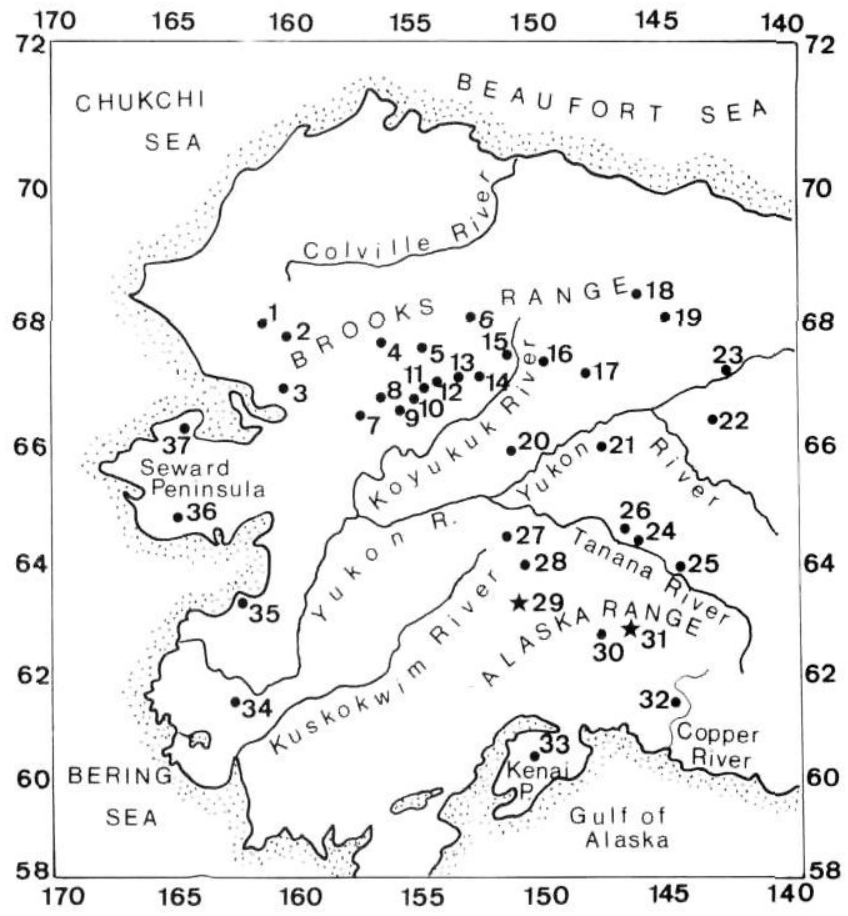

FIGURE 1. Map of Alaska with sites discussed in text. See Table I for site information.

Carte de l'Alaska montrant les sites dont on parle dans le texte (voir tabl. l). 

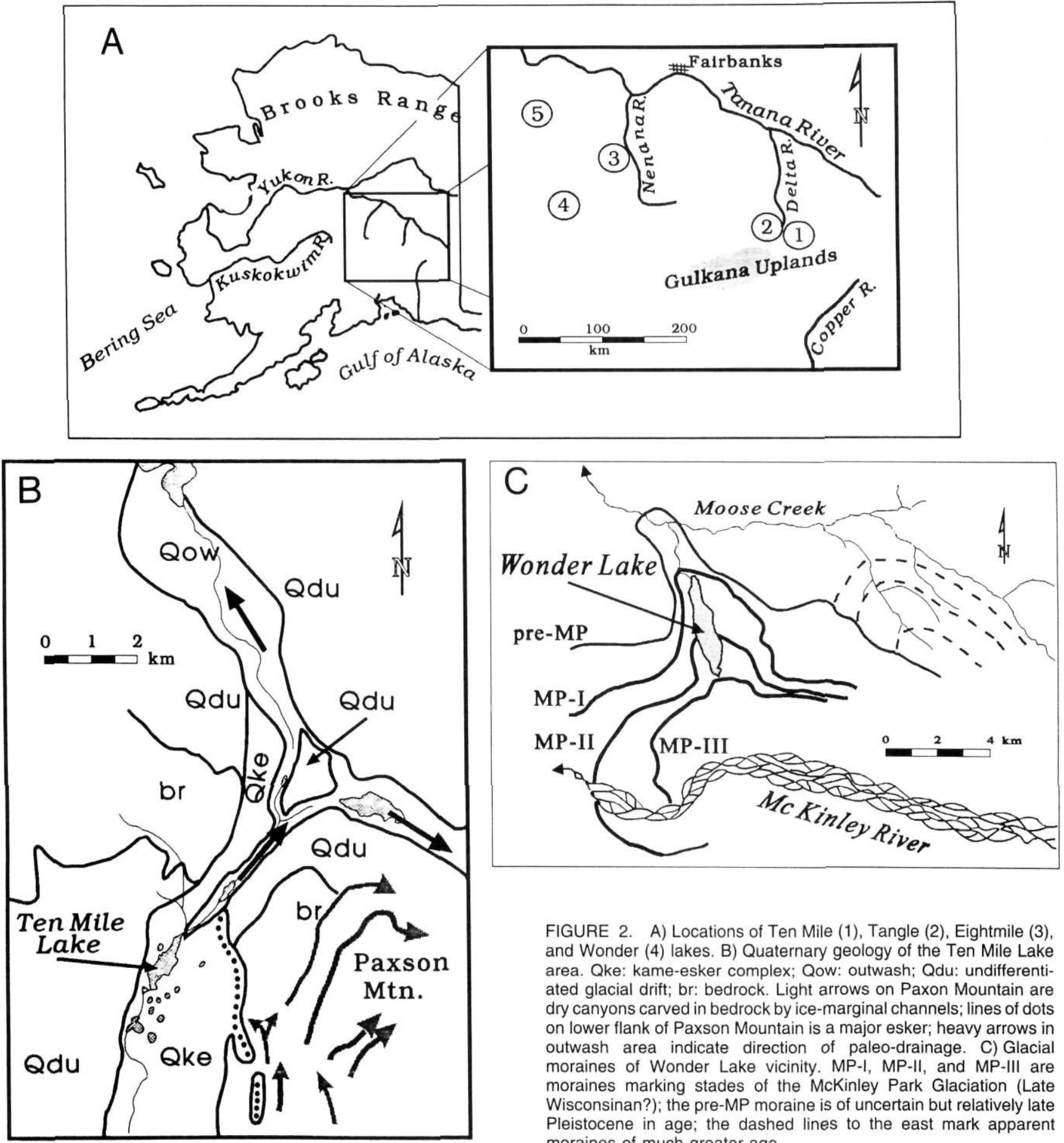

FIGURE 2. A) Locations of Ten Mile (1), Tangle (2), Eightmile (3), and Wonder (4) lakes. B) Quaternary geology of the Ten Mile Lake area. Qke: kame-esker complex; Qow: outwash; Qdu: undifferentiated glacial drift; br: bedrock. Light arrows on Paxon Mountain are dry canyons carved in bedrock by ice-marginal channels; lines of dots on lower flank of Paxson Mountain is a major esker; heavy arrows in outwash area indicate direction of paleo-drainage. C) Glacial moraines of Wonder Lake vicinity. MP-I, MP-II, and MP-III are moraines marking stades of the McKinley Park Glaciation (Late Wisconsinan?); the pre-MP moraine is of uncertain but relatively late Pleistocene in age; the dashed lines to the east mark apparent moraines of much greater age.

Localisation des lacs à l'étude: Ten Mile (1), Tangle (2), Eightmile (3), et Wonder (4). B) Géologie du Quaternaire de la région du Ten Mile Lake. Qke: complexe kame-esker; Qow: épandage fluvio-glaciaire; Qdu: dépôts glaciaires non différencié; br: roche en place. Les flèches qui parcourent Paxon Mountain identifient des canyons secs surcreusés dans la roche en place par des chenaux de contact glaciaire; le pointillé sur les flancs inférieurs de Paxon Mountain donne la direction du paléodrainage. C) Les moraines dans les environs du Wonder Lake. Les moraines MP-I, MP-II et MP-III représentent les différents stades de la Glaciation de McKinley Park (Wisconsinien supérieur?). La moraine " pre-MP ", bien qu'étant d'un âge incertain, date probablement du Pléistocène supérieur. Les tiretés à l'est montrent des moraines beaucoup plus anciennes. 
TABLE I

Site information and key to figures 1 and 5

\begin{tabular}{|c|c|c|c|c|c|}
\hline Site \# & Site Name & Location & Elev. (m) & Rank $^{*}$ & Reference \\
\hline 1 & Kaiyak & $\begin{array}{r}68^{\circ} 09^{\prime} \mathrm{N} \\
161^{\circ} 25^{\prime} \mathrm{W}\end{array}$ & 190 & 1 & Anderson, 1985 \\
\hline 2 & Niliq & $\begin{array}{r}67^{\circ} 52^{\prime} \mathrm{N} \\
160^{\circ} 26^{\prime} \mathrm{W}\end{array}$ & 274 & 2 & Anderson, 1988 \\
\hline 3 & Squirrel & $\begin{array}{r}67^{\circ} 06^{\prime} \mathrm{N} \\
160^{\circ} 23^{\prime} \mathrm{W}\end{array}$ & 91 & 2 & Anderson, 1985 \\
\hline 4 & Etivlik & $\begin{array}{r}68^{\circ} 08^{\prime} \mathrm{N} \\
156^{\circ} 02^{\prime} \mathrm{W}\end{array}$ & 631 & 1 & Anderson, unpub. \\
\hline 5 & Headwaters & $\begin{array}{r}67^{\circ} 56^{\prime} \mathrm{N} \\
155^{\circ} 02^{\prime} \mathrm{W}\end{array}$ & 820 & 1 & Brubaker et al., 1983 \\
\hline 6 & Chandler & $\begin{array}{r}68^{\circ} 15^{\prime} \mathrm{N} \\
152^{\circ} 42^{\prime} \mathrm{W}\end{array}$ & 950 & 0 & Livingstone, 1957 \\
\hline 7 & Joe & $\begin{array}{r}66^{\circ} 46^{\prime} \mathrm{N} \\
157^{\circ} 13^{\prime} \mathrm{W}\end{array}$ & 183 & 4 & Anderson, 1988 \\
\hline 8 & Kollioksak & $\begin{array}{r}66^{\circ} 58^{\prime} \mathrm{N} \\
156^{\circ} 27^{\prime} \mathrm{W}\end{array}$ & 213 & 1 & Anderson, unpub. \\
\hline 9 & Selby & $\begin{array}{r}66^{\circ} 51^{\prime} \mathrm{N} \\
155^{\circ} 43^{\prime} \mathrm{W}\end{array}$ & 145 & 3 & Anderson, unpub. \\
\hline 10 & Minakokosa & $\begin{array}{l}66^{\circ} 55^{\prime} \mathrm{N} \\
155^{\circ} 02^{\prime}\end{array}$ & 122 & 3 & Anderson, unpub. \\
\hline 11 & Ruppert & $\begin{array}{r}67^{\circ} \mathrm{O} 4^{\prime} \mathrm{N} \\
154^{\circ} 15^{\prime} \mathrm{W}\end{array}$ & 210 & 4 & Brubaker et al., 1983 \\
\hline 12 & Angal & $\begin{array}{r}67^{\circ} 08^{\prime} \mathrm{N} \\
153^{\circ} 54^{\prime} \mathrm{W}\end{array}$ & 820 & 1 & Brubaker et al., 1983 \\
\hline 13 & Ranger & $\begin{array}{r}67^{\circ} 09^{\prime} \mathrm{N} \\
153^{\circ} 39^{\prime} \mathrm{W}\end{array}$ & 820 & 1 & Brubaker et al., 1983 \\
\hline 14 & Redstone & $\begin{array}{r}67^{\circ} 15^{\prime} \mathrm{N} \\
152^{\circ} 36^{\prime} \mathrm{W}\end{array}$ & 914 & 1 & Edwards et al., 1985 \\
\hline 15 & $\begin{array}{l}\text { Screaming } \\
\text { Yellowlegs }\end{array}$ & $\begin{array}{r}67^{\circ} 35^{\prime} \mathrm{N} \\
151^{\circ} 25^{\prime} \mathrm{W}\end{array}$ & 650 & 1 & Edwards et al., 1985 \\
\hline 16 & Rebel & $\begin{array}{r}67^{\circ} 25^{\prime} \mathrm{N} \\
149^{\circ} 48^{\prime} \mathrm{W}\end{array}$ & 914 & & Edwards et al., 1985 \\
\hline 17 & Sakana & $\begin{array}{r}67^{\circ} 26^{\prime} \mathrm{N} \\
147^{\circ} 51^{\prime} \mathrm{W}\end{array}$ & 640 & 4 & Brubaker, unpub. \\
\hline 18 & Crowsnest & $\begin{array}{c}68^{\circ} 20^{\prime} \mathrm{N} \\
146^{\circ} 29^{\prime} \mathrm{W}\end{array}$ & 881 & 1 & Anderson, unpub. \\
\hline 19 & Seagull & $\begin{array}{r}68^{\circ} 16^{\prime} \mathrm{N} \\
145^{\circ} 13^{\prime} \mathrm{W}\end{array}$ & 637 & 1 & Brubaker, unpub. \\
\hline
\end{tabular}

\section{WONDER LAKE}

Wonder Lake $\left(63^{\circ} 29^{\prime} \mathrm{N} 151^{\circ} 05^{\prime} \mathrm{W} ; 610 \mathrm{~m}\right)$ occupies the lowland that connects the broad valley of the McKinley River to the south and the canyon of Moose Creek to the north (Fig. $2 \mathrm{C}$ ). The lake is ca. $4.5 \mathrm{~km}$ long and $0.8 \mathrm{~km}$ wide with an outlet to Moose Creek. Maximum depths are greater than $60 \mathrm{~m}$ in the central basin (A. Werner, unpub.). Because this exceeds our coring abilities, we sampled a shallower platform (ca. $11 \mathrm{~m}$ ) in the northern part of the lake.

The vegetation in the Wonder Lake catchment consists of a mosaic of alpine and shrub tundra and open Picea glauca forest. Alpine tundra occurs in the highest areas of the surrounding mountains. Tall Betula-Alnus shrub tundra is restricted to lower elevation mountain slopes and cooler sites in the valley where it is interspersed with Carex marsh in local wetlands. Picea glauca is present below altitudes of $800 \mathrm{~m}$ and is most dense on warm, south-facing slopes. Relatively dense Picea forests also grow along the floodplains of the McKinley River and Moose Creek. Populus balsamifera and,

\begin{tabular}{|c|c|c|c|c|c|}
\hline Site \# & Site Name & Location & Elev. (m) & Rank $^{*}$ & Reference \\
\hline 20 & Sithylemenkat & $\begin{array}{r}66^{\circ} 07^{\prime} \mathrm{N} \\
151^{\circ} 26^{\prime} \mathrm{W}\end{array}$ & 213 & 3 & Anderson et al., 1990 \\
\hline 21 & Sands of Time & $\begin{array}{r}66^{\circ} 02^{\prime} \mathrm{N} \\
147^{\circ} 31^{\prime} \mathrm{W}\end{array}$ & 250 & 3 & Lamb and Edwards, 1988 \\
\hline 22 & Tiinkdhul & $\begin{array}{r}66^{\circ} 35^{\prime} \mathrm{N} \\
143^{\circ} 09^{\prime} \mathrm{W}\end{array}$ & 189 & 4 & Anderson et al., 1988 \\
\hline 23 & Ped & $\begin{array}{r}67^{\circ} 12^{\prime} \mathrm{N} \\
142^{\circ} 04^{\prime} \mathrm{W}\end{array}$ & 211 & 2 & $\begin{array}{l}\text { Edwards and Brubaker, } \\
1987\end{array}$ \\
\hline 24 & Birch & $\begin{array}{r}64^{\circ} 19^{\prime} \mathrm{N} \\
146^{\circ} 50^{\prime} \mathrm{W}\end{array}$ & 274 & 0 & Ager, 1975 \\
\hline 25 & George & $\begin{array}{l}63^{\circ} 47^{\prime} \mathrm{N} \\
144^{\circ} 30^{\prime} \mathrm{W}\end{array}$ & 389 & 0 & Ager, 1975 \\
\hline 26 & Harding & $\begin{array}{r}64^{\circ} 26^{\prime} \mathrm{N} \\
146^{\circ} 52^{\prime} \mathrm{W}\end{array}$ & 217 & 3 & Ager, 1983 \\
\hline 27 & Wein & $\begin{array}{r}64^{\circ} 20^{\prime} \mathrm{N} \\
152^{\circ} 16^{\prime} \mathrm{W}\end{array}$ & 305 & 4 & Hu et al., 1993 \\
\hline 28 & Eightmile & $\begin{array}{r}63^{\circ} 53^{\prime} \mathrm{N} \\
149^{\circ} 15^{\prime} \mathrm{W}\end{array}$ & 646 & 2 & Ager, 1983 \\
\hline 29 & Wonder & $\begin{array}{r}63^{\circ} 29^{\prime} \mathrm{N} \\
151^{\circ} 05^{\prime} \mathrm{W}\end{array}$ & 610 & 0 & - \\
\hline 30 & Tangle & $\begin{array}{r}63^{\circ} 02^{\prime} \mathrm{N} \\
146^{\circ} 04^{\prime} \mathrm{W}\end{array}$ & 850 & 1 & Schweger, 1981 \\
\hline 31 & Tenmile & $\begin{array}{l}63^{\circ} 04^{\prime} \mathrm{N} \\
145^{\circ} 42^{\prime} \mathrm{W}\end{array}$ & 1000 & 1 & - \\
\hline 32 & 70 Mile & $\begin{array}{r}61^{\circ} 30^{\prime} \mathrm{N} \\
145^{\circ} 14^{\prime} \mathrm{W}\end{array}$ & 548 & 3 & Ager and Brubaker, 1985 \\
\hline 33 & Hidden & $\begin{array}{r}60^{\circ} 29^{\prime} \mathrm{N} \\
150^{\circ} 17^{\prime} \mathrm{W}\end{array}$ & 91 & 2 & Ager, 1983 \\
\hline 34 & Tungak & $\begin{array}{r}61^{\circ} 23^{\prime} \mathrm{N} \\
164^{\circ} 01^{\prime} \mathrm{W}\end{array}$ & 122 & 0 & Ager, 1982 \\
\hline 35 & Puyuk & $\begin{array}{r}63^{\circ} 29^{\prime} \mathrm{N} \\
160^{\circ} 02^{\prime} \mathrm{W}\end{array}$ & 14 & 1 & Ager, 1982 \\
\hline 36 & Glacial & $\begin{array}{r}64^{\circ} 53^{\prime} \mathrm{N} \\
165^{\circ} 42^{\prime} \mathrm{W}\end{array}$ & 119 & 1 & Eisner, unpub. \\
\hline 37 & Whitefish & $\begin{array}{r}66^{\circ} 04^{\prime} \mathrm{N} \\
165^{\circ} 03^{\prime} \mathrm{W}\end{array}$ & 12 & 1 & Anderson, unpub. \\
\hline
\end{tabular}

- Rank based on percentage of Populus pollens from 9000 to 11,000 BP (see also Fig. 5).

more rarely, $P$. tremuloides, comprise the broadleaf deciduous component of the vegetation.

Wonder Lake lies within a broad belt of morainal topography evidently of Late Wisconsinan age (Fig. 2C; McKinley Park glaciation of Werner, 1982, 1992). The lake is confined to the north by the outermost morainal ridge in this complex (MP-I), and it is blocked to the south by a broad moraine (MP-III) marking either a readvance or a major surge. Midway between these two moraines is a pair of morainal ridges (MP-II) that apparently record a minor readvance or a surge; they slope northward along either side of Wonder Lake and seem to be connected by a minor submarine ridge that bisects the lake's deepest basin (Werner, unpub.).

Although the Wonder Lake area has been free of glacial influence since some time in the Late Wisconsinan, it was repeatedly glaciated at earlier times (Ten Brink and Waythomas, 1985; Werner, 1982, unpub. data). Air photos suggest that a glacial advance recorded by what appears to be a massive and very ancient moraine and outwash complex 
(Fig. 2C) displaced Moose Creek into its present canyon, but previously the open valley of upper Moose Creek was a tributary to the McKinley River. These ancient deposits are transected farther west by a series of younger moraines that wrap around Wonder Lake. (Note: Werner (unpub.) suggests that glacial erosion may have gouged the lake basin itself from a pre-existing bedrock fault zone extending north from Moose Creek.) The outermost moraine extends beyond Wonder Lake for a short distance down Moose Creek; its subdued appearance suggests that it may correspond to the preWisconsinan Healy moraine of the Nenana Valley (Wahrhaftig, 1958).

\section{METHODS}

Cores were collected in summer, 1990, with a modified Livingstone piston sampler (Wright et al., 1984). Undisturbed uppermost sediments were collected with a plexiglass corer, although samples from these cores were used only in the Ten Mile diagram (see Results). The Ten Mile core was analyzed at the Ohio State University, whereas Wonder Lake pollen counts were done at the North East Interdisciplinary Institute. One cubic centimeter samples from all of the Ten Mile Lake and some of Wonder Lake cores were prepared following standard procedures for North American arctic lakes (Faegri and Iversen, 1989; Cwynar et al., 1979; Stockmarr, 1971). Because of limitations of chemical availability, other Wonder Lake samples were prepared following the heavy-liquid method of Grichuk and Zaklinskaya (1948). A minimum of 300 known terrestrial pollen grains form the pollen sum. Spores and aquatics are calculated as percent of pollen sum. Pollen zones were defined qualitatively from pollen percentage diagrams. Pollen accumulation rates (PAR) for Ten Mile Lake were calculated by simple linear interpolation between radiocarbon dated levels (Table II). A PAR diagram was not constructed for Wonder Lake because of questionable radiocarbon dates (see Radiocarbon below). Proportions of Picea glauca to Picea mariana pollen grains (theta values; Table III) were calculated for select samples by a maximum likelihood technique (Brubaker et al., 1987). Percent loss on-ignition was determined by ashing samples at $550^{\circ} \mathrm{C}$ after oven drying at $90^{\circ} \mathrm{C}$ (Table IV).

TABLE ॥

Radiocarbon Dates

\begin{tabular}{ccc}
\hline Depth $(\mathrm{cm})$ & Date & Lab No. \\
\hline $\begin{array}{c}\text { Ten Mile Lake: } \\
70-86\end{array}$ & $3270 \pm 90$ & \\
$178-188$ & $7330 \pm 110$ & BETA-42704 \\
$214-224$ & $9140 \pm 80$ & BETA-42705 \\
$276-288$ & $11540 \pm 120$ & BETA-42706 \\
Wonder Lake: & & BETA-42707 \\
$74-84$ & $5330 \pm 120$ & \\
$115-125$ & $7000 \pm 100$ & BETA-43474 \\
$166-175$ & $9820 \pm 110$ & BETA-42589 \\
$195-205$ & $11270 \pm 280$ & BETA-42590 \\
$215-225$ & $12760 \pm 110$ & BETA-42591 \\
$250-260$ & $13550 \pm 140$ & BETA-43475 \\
\hline
\end{tabular}

\section{RESULTS}

\section{POLLEN DIAGRAMS}

\section{Ten Mile Lake}

Three pollen zones were defined at Ten Mile Lake (Fig. 3). $\mathrm{TM}-1$, which includes subzones TM-1A and TM-1B, is dominated by Betula pollen (40-60\%; 61-422 grains $\mathrm{cm}^{2} \mathrm{yr}^{-1}$ ) with relatively high percentages of Salix $(7-15 \%)$ and Gramineae $(3-11 \%)$ as compared to the rest of the core. Populus, Juniperus, and Ericales pollen are present in trace amounts in this and other zones. Percentages of Cyperaceae pollen (10-37\%) are highest in TM-1A, although PARs (40-80 grains $\mathrm{cm}^{2} \mathrm{yr}^{-1}$ ) imply Cyperaceae was more abundant in TM-1B. The highest Artemisia PARs in the core occur in TM-1B.

TM-2 is characterized by a sharp increase in Picea pollen percentages (23-41\%) and PARs (83-118 grains $\left.\mathrm{cm}^{2} \mathrm{yr}^{-1}\right)$. Salix $(3-4 \%)$ and Betula $(31-44 \%)$ pollen percentages decrease, as do PARs for Salix ( 7 grains $\left.\mathrm{cm}^{2} \mathrm{yr}^{-1}\right)$, Betula (172 grains $\left.\mathrm{cm}^{2} \mathrm{yr}^{-1}\right)$, Gramineae (3-14 grains $\mathrm{cm}^{2} \mathrm{yr}^{-1}$ ) and Cyperaceae (30-49 grains $\mathrm{cm}^{2} \mathrm{yr}^{-1}$ ).

The beginning of TM-3 is marked by an increase in percentages and PARs of Alnus pollen (15-30\%; $18-170$ grains

TABLE III

Theta Values for Ten Mile and Wonder Lakes

\begin{tabular}{|c|c|c|}
\hline Depth (cm) & Theta $^{1}$ & Standard Error \\
\hline \multicolumn{3}{|c|}{ Ten Mile Lake: } \\
\hline 0 & 0.619 & 0.134 \\
\hline 4 & 0.748 & 0.123 \\
\hline 8 & 0.552 & 0.137 \\
\hline 10 & 0.665 & 0.131 \\
\hline 18 & 0.494 & 0.137 \\
\hline 28 & 0.642 & 0.133 \\
\hline 38 & 0.937 & 0.083 \\
\hline 48 & 0.523 & 0.137 \\
\hline 68 & 0.277 & 0.127 \\
\hline 88 & 0.277 & 0.127 \\
\hline 103 & 0.422 & 0.136 \\
\hline 108 & 0.831 & 0.111 \\
\hline 126 & 0.669 & 0.134 \\
\hline 154 & 0.318 & 0.131 \\
\hline 163 & 0.052 & 0.080 \\
\hline 172 & 0.818 & 0.113 \\
\hline 196 & 1.000 & * \\
\hline 201 & 1.000 & * \\
\hline 216 & 0.930 & 0.079 \\
\hline \multicolumn{3}{|l|}{ Wonder Lake } \\
\hline 100 & 0.001 & * \\
\hline 120 & 0.167 & 0.112 \\
\hline 140 & 0.407 & 0.136 \\
\hline 161 & 0.998 & 0.038 \\
\hline 180 & 0.775 & 0.120 \\
\hline 200 & 0.917 & 0.091 \\
\hline \multicolumn{3}{|c|}{$\begin{array}{l}\text { Theta values greater than } 0.8 \text { are interpreted to indicate a domi- } \\
\text { nance of Picea glauca trees on the landscape (Anderson and } \\
\text { Brubaker, 1986). } \\
\text { * Convergence criteria not met, suggesting samples that are nona- } \\
\text { nalogous to modern Picea populations. }\end{array}$} \\
\hline
\end{tabular}


TABLE IV

Percent loss-on-ignition

\begin{tabular}{|c|c|c|c|}
\hline \multicolumn{2}{|c|}{ Wonder Lake } & \multicolumn{2}{|c|}{ Ten Mile Lake } \\
\hline Depth $(\mathrm{cm})$ & $\%$ Orqanic & Depth (cm) & $\%$ Organic \\
\hline 12 & 9.8 & 0 & 5.7 \\
\hline 23 & 12.3 & 10 & 5.5 \\
\hline 35 & 11.1 & 20 & 5.2 \\
\hline 50 & 11.6 & 30 & 5.5 \\
\hline 67 & 11.9 & 40 & 3.6 \\
\hline 72 & 12.2 & 50 & 5.8 \\
\hline 82 & 3.5 & 60 & 7.6 \\
\hline 92 & 14.6 & 70 & 6.5 \\
\hline 100 & 11.4 & 80 & 6.6 \\
\hline 115 & 12.1 & 90 & 6.5 \\
\hline 129 & 12.0 & 100 & 6.2 \\
\hline 149 & 11.0 & 110 & 7.7 \\
\hline 152 & 8.1 & 120 & 5.1 \\
\hline 161 & 11.6 & 125 & 2.1 \\
\hline 172 & 9.7 & 130 & 8.3 \\
\hline 180 & 6.5 & 140 & 9.7 \\
\hline 189 & 6.3 & 150 & 8.8 \\
\hline 200 & 10.8 & 160 & 7.4 \\
\hline 205 & 9.9 & 170 & 13.1 \\
\hline 213 & 9.2 & 180 & 8.2 \\
\hline 240 & 7.7 & 190 & 8.4 \\
\hline 252 & 4.3 & 200 & 7.6 \\
\hline 271 & 3.6 & 210 & 8.8 \\
\hline 283 & 2.9 & 220 & 9.8 \\
\hline 290 & 6.1 & 230 & 12.9 \\
\hline 297 & 1.1 & 240 & 12.9 \\
\hline 300 & 6.0 & 250 & 10.6 \\
\hline 306 & 6.4 & 260 & 9.0 \\
\hline \multirow[t]{2}{*}{308} & 7.1 & 270 & 4.8 \\
\hline & & 280 & 6.2 \\
\hline
\end{tabular}

$\mathrm{cm}^{2} \mathrm{yr}^{-1}$ ). Percentages of Picea pollen remain high (>20\%) throughout TM-3, with a slight increase in the uppermost samples. Picea thetas are generally below 0.8 , indicating a predominance of $P$. mariana from 0 to $163 \mathrm{~cm}$ (Table III).

\section{Wonder Lake}

The Wonder Lake core has four pollen zones (Fig. 4). The oldest, WL-1, is dominated by Cyperaceae pollen (up to $70 \%$ ) with substantial representation of Salix (up to $9 \%$ ), Gramineae (up to $13 \%$ ), Artemisia (up to $9 \%$ ), and other herbaceous (up to $12 \%$ ) pollen.

WL-2 is characterized by high percentages of Betula pollen (53-78\%). WL-2A has low but consistent amounts of Salix (ca. $2 \%)$, Gramineae $(3-15 \%)$, and Artemisia $(<5 \%)$ pollen, and within-zone variations in Cyperaceae percentages $(6-32 \%)$. WL-2B is distinguished from WL-2A by slight rises in Picea (ca. $8 \%$ ) and Alnus (ca. $5 \%$ ) pollen. Picea grains were measured in two samples and thetas indicate a predominance of $P$. glauca pollen (Table III).

Increased percentages of Alnus pollen (35-43\%) with low but significant Picea percentages (7-13\%) and moderate Betula percentages $(35-44 \%)$ define WL-3. This pollen assemblage contrasts to the Ten Mile core, where the Picea pollen rise is rapid and precedes the major increase in Alnus pollen. A lower theta at $140 \mathrm{~cm}(c f .161 \mathrm{~cm})$ indicates a shift from primarily $P$. glauca pollen to $P$. mariana pollen within WL-3.

Pollen spectra in WL-4 are similar to WL-3 except Picea percentages $(>25 \%)$ are greater, resulting in a slight decrease in Alnus and Betula pollen percentages (generally $(<30 \%)$. Picea pollen percentages $(<30 \%)$ decrease in the uppermost samples in WL-4 and low thetas suggest the continued importance of $P$. mariana pollen. A $32 \mathrm{~cm}$ plexiglass core (not illustrated here) could not be correlated with the Livingstone core, because of differences in pollen assemblages between the two cores (e.g., Picea percentages exceed $50 \%$ in all plexiglass samples). This dissimilarity is difficult to explain, because the cores were taken side-byside. Because of this ambiguity, we are reluctant to interpret the uppermost changes in Picea percentages at Wonder Lake as actual shifts in treeline.

\section{RADIOCARBON DATES}

Bulk sediment samples from both lakes were submitted for radiocarbon analyses (Table II). We think the Ten Mile dates are correct, because they are consistent with the regional chronostratigraphy (see Discussion). For the same reasons, the dates of the $166-175 \mathrm{~cm}, 195-205 \mathrm{~cm}$, and possibly $215-225 \mathrm{~cm}$ samples from Wonder Lake seem suspiciously old. The presence of nearly $10 \%$ Picea at depths corresponding to ages of ca. 11,000 to 10,000 BP suggest an unusually early presence of trees within the Wonder Lake watershed (Anderson and Brubaker, 1986). The earlier arrival of Picea at Wonder Lake than at sites in eastern Alaska, where Picea is present ca. 9000 to $9500 \mathrm{BP}$, is unlikely, given Wonder Lake's greater distance from presumed postglacial source areas in northwestern Canada (Edwards and Brubaker, 1986). The presence of Late Wisconsinan piedmont glaciers in the proximity of Wonder Lake makes it equally difficult to imagine the presence of a full-glacial Picea refugium in nearby valleys. However, it must be noted that the $215-225 \mathrm{~cm}$ date at Wonder Lake is not completely unreasonable, and the $250-260 \mathrm{~cm}$ date corresponds to similar pollen stratigraphic changes at Eightmile Lake (Ager, 1983).

Sediment contamination by old carbon may be the cause of the apparent dating anomalies at Wonder Lake (MacDonald et al., 1991). Bedrock within the Wonder Lake catchment includes small belts of carbonate rocks (Reed, 1961). A wide belt of Tertiary coal-bearing sediments, which extends below the McKinley valley just south (i.e., up-glacier) from Wonder Lake, is perhaps a more significant contamination source. Finely ground lignite and/or carbonate from glacial scouring could have been easily redeposited in the moraines surrounding the lake. As postglacial erosional processes continued, these materials eventually would wash into the Wonder basin. The error associated with the input of dead carbon could vary throughout the core, depending on amount of vegetation cover, degree of soil development, and the proportion of contemporary carbon (i.e., larger amounts of old carbon are required in younger sediments to produce comparable errors), thereby accounting for some dates that seem reasonable and some that seem too old. 


\section{VEGETATION HISTORY OF WONDER AND TEN MILE LAKES}

The Wonder Lake catchment during latest glacial times was a treeless landscape dominated by herbs and Salix shrubs. The variety of minor herb taxa (Table V) indicate a mosaic of xeric and mesic communities (e.g., Compositae, Cruciferae, Ranunculaceae). Picea, Betula, and Alnus were probably absent from the watershed, with the small amounts of their pollen representing long-distance transport. Given the proximity of Late Wisconsinan glaciers to the lake, the predominance of Cyperaceae and Salix pollen may reflect very local shoreline vegetation, with much of the bordering hillsides supporting sparse xeric communities. The low organic content of the sediment further suggests a non-productive lake system and minimal overland flow of organic material
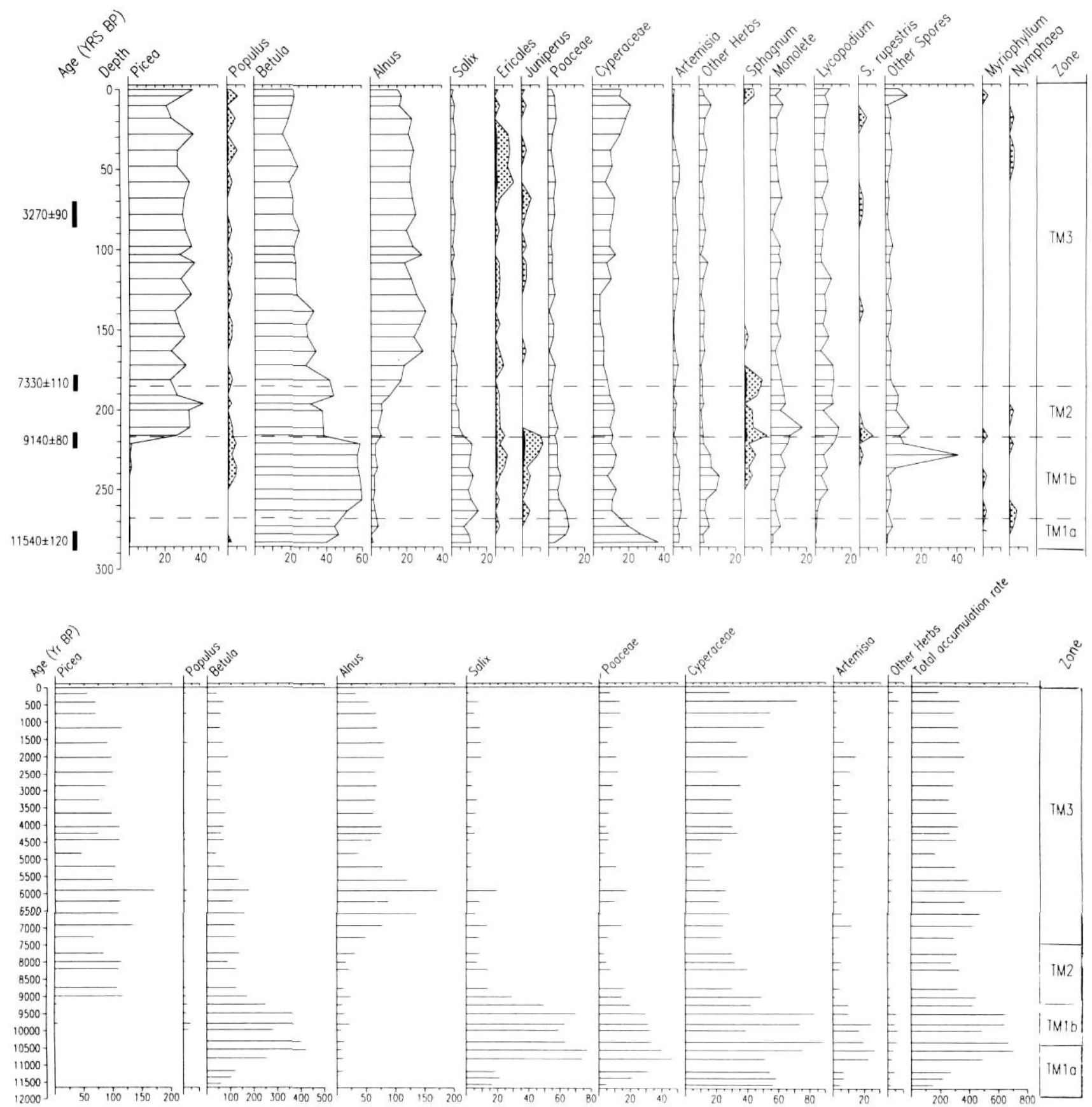

FIGURE 3. Pollen diagrams from Ten Mile Lake. A) Percentage diagram of major taxa. Percents are calculated based on all identified and unindentified pollen. Stippled pattern indicates $7 x$ exaggeration. B) Accumulation rate diagram. Rates are expressed as number of grains deposited per $\mathrm{cm}^{2}$ per $\mathrm{yr}$.
Diagrammes polliniques du Ten Mile Lake. A) Diagramme en pourcentages des principaux taxons. Les pourcentages sont calculés sur la base de tout le pollen identifié et non identifié. Il y a eu exagération de $7 x$ là où la trame est en pointillé. B) Diagramme du taux d'accumulation. Les taux sont fondés sur le nombre de grains déposés par $\mathrm{cm}^{2} / \mathrm{a}$. 


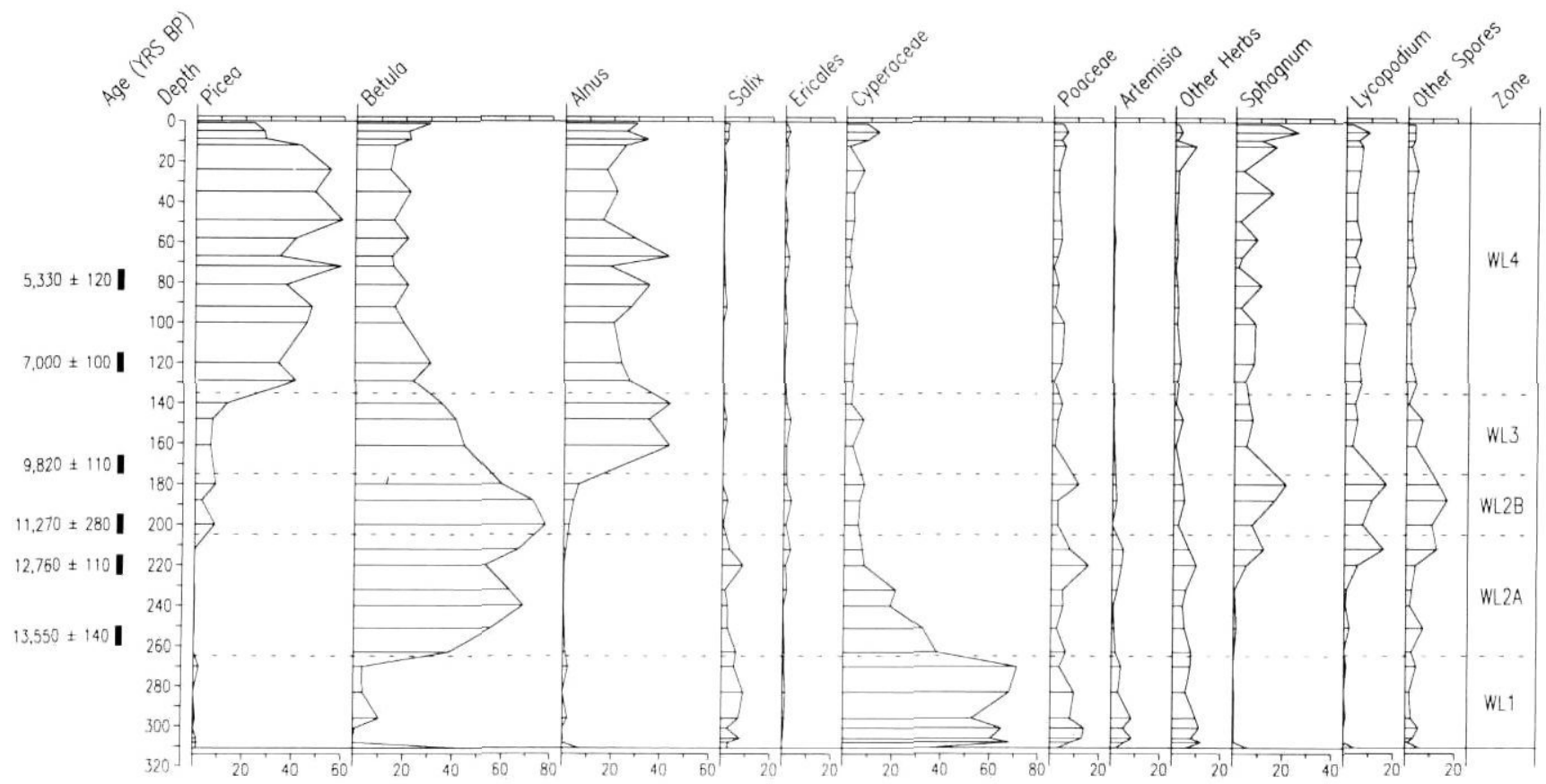

FIGURE 4. Percentage diagram of major taxa for Wonder Lake. Percents are calculated based on all identified and unidentified pollen.

into the basin. Probably the most favorable hillsides and lowlands supported a mesic graminoid tundra. Salix probably dominated scattered riparian and snowbed communities.

Betula shrubs established near Wonder Lake possibly as early as 13,500 BP. Pollen percentages at Ten Mile Lake suggest Betula was present by at least 11,500 BP, but PARs imply it was most abundant between 10,700 to $9300 \mathrm{BP}$. The vegetation during this period near Ten Mile Lake, and possibly Wonder Lake, may have been similar to the high Betula shrub tundra found in the forest-tundra ecotone of the modern Gulkana Uplands (Viereck et al., 1992).

Populus pollen is absent from Wonder Lake, suggesting the tree was never present in the watershed. In contrast, Populus pollen occurs in trace amounts throughout the Ten Mile record beginning ca. 10,000 BP. A slight rise in Populus pollen at ca. 10,000 BP is also reported for nearby Tangle Lake (Schweger, 1981; Fig. 1). Interpretation of such minor but consistent percentages of Populus is difficult. Similar percentages occur in samples of modern pollen rain from lakes that have Populus growing along the shore as well as lakes located within the tundra hundreds of kilometers from Populus groves (Anderson and Brubaker, unpub. data). The similarity of ancient with modern percentages at Ten Mile, where Populus is currently absent, suggests that the tree probably never grew near the lake and that the pollen likely blew in from nearby populations (e.g., the Delta or Copper River valleys; Ager and Brubaker, 1985; see also Discussion).

The Picea curve from Wonder Lake is unusual for, unlike other Alaskan diagrams, the main Picea increase is preceded by a period of constant, moderately high percentages (i.e., between 150 and $205 \mathrm{~cm}$ ). These Picea percentages, which
Diagramme en pourcentages des principaux taxons du Wonder Lake. Les pourcentages sont calculées sur la base de tout le pollen identifié et non identifié.

are primarily $P$. glauca, are below the $10 \%$ threshold conventionally used to infer Picea presence, but well above the trace $(<2 \%)$ amounts typical for sites receiving Picea pollen from long distance wind transport (Anderson and Brubaker, 1986). However, Hu et al. (1993), based on pollen and macrofossil data from Wein Lake, conclude that Picea trees can occur in a watershed when pollen percentages are as low as $5 \%$. These results suggest that Picea may have existed in low numbers near Wonder Lake for some time prior to the establishment of larger forested areas. If the radiocarbon dates are correct, Picea could have established ca. 11,300 BP, which would be the earliest postglacial date for Picea in Alaska. Alternatively, the moderate Picea percentages could reflect a long distance source. Both interpretations are problematic, because the presence of a full-glacial Picea refugium at high elevation near alpine glaciers is unlikely, and a distant source area is difficult to define given the apparent arrival of Picea from northwestern Canada between 10,000 and 9000 BP (Edwards and Brubaker, 1986). We think that significant Picea populations were absent in the Wonder Lake region until ca. 7000 to $7500 \mathrm{BP}$, when the pollen spectra approximate the modern ones and $P$. mariana is the dominant Picea taxon.

The Picea curve from the upper $140 \mathrm{~cm}$ of the Wonder Lake core is equally problematic. Percentages generally exceed $40 \%$, except for the uppermost $10 \mathrm{~cm}$. Few modern pollen spectra in Alaska have such high Picea percentages, but those that do are from lakes in closed $P$. mariana forests (Anderson and Brubaker, 1986). In contrast, modern sites near treeline typically have $10 \%$ Picea pollen. The presence of a closed boreal forest in the Wonder Lake area during much of the Holocene seems doubtful (see Discussion), and 
TABLE V

Taxa Included in Other Herb Category

\begin{tabular}{|c|c|c|c|}
\hline Depth $(\mathrm{cm})$ & Taxa & Depth $(\mathrm{cm})$ & Taxa \\
\hline \multicolumn{2}{|l|}{ Wonder Lake } & 58 & Rosaceae, Saxifragaceae, Tubliflorae \\
\hline \multirow[t]{2}{*}{12} & \multirow{2}{*}{$\begin{array}{l}\text { Lamiaceae, Polygonaceae, Rosaceae, } \\
\text { Saxifragaceae, Scrophulariaceae, Tubliflorae, } \\
\text { Thalictrum, }\end{array}$} & 68 & $\begin{array}{l}\text { Caryophyllaceae, Rosaceae, Saxifragaceae, } \\
\text { Valerianaceae, Rumex }\end{array}$ \\
\hline & & 78 & $\begin{array}{l}\text { Cruciferae, Rosaceae, Saxifragaceae, } \\
\text { Umbelliferae, Valerianaceae }\end{array}$ \\
\hline \multirow[t]{2}{*}{58} & \multirow{2}{*}{$\begin{array}{l}\text { Liliaceae, Onagraceae, Polemoniaceae, } \\
\text { Rosaceae, Saxifragaceae, Polygonum sect. } \\
\text { Bistorta }\end{array}$} & 88 & $\begin{array}{l}\text { Cruciferae, Rosaceae, Saxifragaceae, Polygonum } \\
\text { sect. Bistorta, Saxifraga tricuspidata }\end{array}$ \\
\hline & & 98 & Rosaceae, Saxifragaceae \\
\hline 81 & Ranunculaceae, Saxifragaceae, Rosaceae & 103 & Rosaceae, Saxifragaceae, \\
\hline 100 & $\begin{array}{l}\text { Rosaceae, Saxifragaceae, Tubliflorae, } \\
\text { Valerianaceae, Polygonum sect. Bistorta }\end{array}$ & 108 & $\begin{array}{l}\text { Ranunculaceae, Rosaceae, Saxifragaceae, } \\
\text { Tubliflorae, Umbelliferae, Valerianaceae, Rumex }\end{array}$ \\
\hline 120 & $\begin{array}{l}\text { Caryophyllaceae, Rosaceae, Saxifragaceae, } \\
\text { Polygonum sect. Bistorta, Thalictrum }\end{array}$ & 118 & $\begin{array}{l}\text { Rosaceae, Saxifragaceae, Tubliflorae, } \\
\text { Valerianaceae }\end{array}$ \\
\hline 140 & \multirow{2}{*}{$\begin{array}{l}\text { Rosaceae, Saxifragaceae, Polygonum sect. } \\
\text { Bistorta }\end{array}$} & \multirow[b]{2}{*}{138} & Rosaceae, Saxifragaceae \\
\hline 161 & & & $\begin{array}{l}\text { Cruciferae, Onagraceae, Polemoniaceae, } \\
\text { Rosaceae, Saxifragaceae }\end{array}$ \\
\hline 180 & $\begin{array}{l}\text { Saxifragaceae, Tubliflorae, Polygonum sect. } \\
\text { Bistorta, Thalictrum, }\end{array}$ & 146 & $\begin{array}{l}\text { Rosaceae, Valerianaceae, Polygonum sect. } \\
\text { Bistorta }\end{array}$ \\
\hline 200 & $\begin{array}{l}\text { Liliaceae, Ranunculaceae, Saxifragaceae, } \\
\text { Tubliflorae }\end{array}$ & 154 & $\begin{array}{l}\text { Rosaceae, Saxifragaceae, Polygonum sect. } \\
\text { Bistorta, Saxifraga tricuspidata }\end{array}$ \\
\hline \multirow[t]{2}{*}{220} & \multirow{2}{*}{$\begin{array}{l}\text { Cruciferae, Polygonaceae, Rosaceae, } \\
\text { Ranunculaceae, Saxifragaceae, Scrophulariaceae, } \\
\text { Umbelliferae, Polygonum sect. Bistorta }\end{array}$} & 163 & $\begin{array}{l}\text { Cruciferae, Ranunculaceae, Rosaceae, Polygonum } \\
\text { sect. Bistorta }\end{array}$ \\
\hline & & 172 & Caryophyllaceae, Rosaceae \\
\hline \multirow[t]{2}{*}{240} & \multirow{2}{*}{$\begin{array}{l}\text { Liliaceae, Polygonaceae, Rosaceae, } \\
\text { Saxifragaceae, Valerianaceae, Polygonum sect. } \\
\text { Bistorta, Thalictrum }\end{array}$} & 181 & Onagraceae, Rosaceae, Rumex \\
\hline & & 191 & Rosaceae \\
\hline \multirow[t]{3}{*}{263} & \multirow{3}{*}{$\begin{array}{l}\text { Chenopodiaceae, Onagraceae, Polygonaceae, } \\
\text { Ranunculaceae, Tubliflorae, Saxifragaceae, } \\
\text { Scrophulariaceae, Polygonum sect. Bistorta, } \\
\text { Thalictrum, }\end{array}$} & 196 & $\begin{array}{l}\text { Rosaceae, Saxifragaceae, Polygonum sect. } \\
\text { Bistorta }\end{array}$ \\
\hline & & 200 & Rosaceae \\
\hline & & 211 & Rosaceae, Valerianaceae \\
\hline \multirow[t]{2}{*}{283} & \multirow{2}{*}{$\begin{array}{l}\text { Chenopodiaceae, Liliaceae, Gentianaceae, } \\
\text { Ranunculaceae, Rosaceae, Saxifragaceae, } \\
\text { Scrophulariaceae, Tubliflorae, Rumex }\end{array}$} & 216 & Caryophyllaceae, Rosaceae, Saxifragaceae \\
\hline & & 221 & Rosaceae, Rumex \\
\hline \multirow[t]{2}{*}{301} & \multirow{2}{*}{$\begin{array}{l}\text { Caryophyllaceae, Polemoniaceae, Polygonaceae, } \\
\text { Ranunculaceae, Rosaceae, Rubiaceae, } \\
\text { Saxifragaceae, Polygonum sect. Bistorta, } \\
\text { Thalictrum }\end{array}$} & 228 & $\begin{array}{l}\text { Caryophyllaceae, Rosaceae, Saxifragaceae, } \\
\text { Polygonum sect. Bistorta, Rumex }\end{array}$ \\
\hline & & 236 & $\begin{array}{l}\text { Ranunculaceae, Rosaceae, Saxifragaceae, } \\
\text { Tubliflorae, Umbelliferae, Saxifraga tricuspidata }\end{array}$ \\
\hline \multicolumn{2}{|l|}{ Ten Mile Lake } & 241 & $\begin{array}{l}\text { Caryophyllaceae, Ranunculaceae, Rosaceae, } \\
\text { Saxifragaceae, Tubliflorae }\end{array}$ \\
\hline 0 & Cruciferae, Ranunculaceae, Rosaceae & 250 & Chenopodiaceae, Onagraceae, Ranunculaceae, \\
\hline \multirow[t]{2}{*}{4} & \multirow{2}{*}{$\begin{array}{l}\text { Rosaceae, Polemoniaceae, Tubliflorae, } \\
\text { Valerianaceae, Polygonum sect. Amphibium }\end{array}$} & & Rosaceae, Saxifragaceae \\
\hline & & 256 & $\begin{array}{l}\text { Caryophyllaceae, Rosaceae, Saxifragaceae, } \\
\text { Tubliflorae, Rumex }\end{array}$ \\
\hline 10 & $\begin{array}{l}\text { Rosaceae, Tubliflorae, Saxifragaceae, } \\
\text { Valerianaceae, Rumex }\end{array}$ & 263 & $\begin{array}{l}\text { Chenopodiaceae, Polemoniaceae, Rosaceae, } \\
\text { Saxifragaceae }\end{array}$ \\
\hline 18 & $\begin{array}{l}\text { Rosaceae, Saxifragaceae, Tubliflorae, Saxifraga } \\
\text { tricuspidata }\end{array}$ & 273 & $\begin{array}{l}\text { Chenopodiaceae, Ranunculaceae, Rosaceae, } \\
\text { Saxifragaceae, Valerianaceae }\end{array}$ \\
\hline \multirow[t]{2}{*}{28} & \multirow{2}{*}{$\begin{array}{l}\text { Cruciferae, Rosaceae, Umbelliferae, } \\
\text { Saxifragaceae, Rumex }\end{array}$} & 278 & Chenopodiaceae, Rosaceae, Tubliflorae, Rumex \\
\hline & & 283 & Chenopodiaceae, Rosaceae, Saxifragaceae, \\
\hline \multirow[t]{2}{*}{38} & \multirow{2}{*}{$\begin{array}{l}\text { Ranunculaceae, Rosaceae, Saxifragaceae, } \\
\text { Valerianaceae, Polygonum sect. Amphibium }\end{array}$} & & $\begin{array}{l}\text { Tubliflorae } \\
\text { Rosaceae }\end{array}$ \\
\hline & & 288 & Rosaceae \\
\hline
\end{tabular}


the high Picea percentages probably reflect overrepresentation of lowland species as documented for other mountainous regions (Gaudreau and Webb, 1985). A recent change in Picea populations, as suggested by a decline of Picea percentages in the uppermost part of the core, is also questionable, because Picea percentages from a plexiglass core taken adjacent to the Livingstone site do not show a similar pattern. Additional data will be needed before conclusions can be made about recent treeline behavior near Wonder Lake.

The Picea percentages (ca. $20-30 \%$ ) in the Ten Mile core are more typical of forested areas, although these data may reflect the effects of wind dispersal from Picea populations in nearby valleys. Picea measurements suggest the early Holocene population was predominantly $P$. glauca with $P$. mariana becoming important ca. 7000 BP. Although Picea percentages do not vary greatly in this core, slight fluctuations in PARs provide some tantalizing evidence for shifting treeline positions during the Holocene. Picea PARs are highest (>100 grains $\mathrm{cm}^{2} \mathrm{yr}^{-1}$ ) between ca. 9000 to $8000 \mathrm{BP}$ and 7000 to $5900 \mathrm{BP}$, with lowest values ca. 8000 to $7000 \mathrm{BP}$ and near core top. These data may indicate that treeline was at higher elevation during the early Holocene followed by a retreat between 8000 and 7000 BP. The decline in Picea PARs over the last 1000 years is probably spurious, reflecting use of water-rich samples from the plexiglass corer. These inferences concerning changing treeline location must be taken very skeptically, but the data are not inconsistent with the regional patterns discussed later.

Alnus is the last major pollen taxon to appear at both sites. Alnus establishes ca. $7300 \mathrm{BP}$ at Ten Mile Lake. The time of arrival of Alnus in the Wonder catchment is less certain, but probably occurred before $7000 \mathrm{BP}$ and possibly as early as $9800 \mathrm{BP}$. Although the radiocarbon results suggest that Alnus may have been present as early as $9800 \mathrm{BP}$, such an early age is unlikely because pollen records from other sites indicate Alnus spread throughout most of Alaska between 8000 and 7000 BP (Anderson and Brubaker, in press; Hu et al., 1993). Although Alnus percentages are high in both the Ten Mile and Wonder diagrams, the shrubs probably were restricted to riparian thickets, lake-shore communities, and/or mountain draws.

\section{DISCUSSION}

\section{FOREST DEVELOPMENT IN SOUTH-CENTRAL ALASKA}

The earliest evidence of trees in south-central Alaska is from Hidden Lake, central Kenai Peninsula (Fig. 1), where scattered stands of Populus occurred ca. 10,300 BP (Ager and Brubaker, 1985). Populus established near Ten Mile, Tangle, and Eightmile Lakes by ca. 10,000 (Schweger, 1981; Ager, 1983). The 70 Mile Lake (Fig. 1) record indicates that Populus arrived in or near the uplands bordering the Copper River some time prior to $9100 \mathrm{BP}$, but inadequate dating prevents more precise estimates of the time of establishment. These results suggest that Populus expanded quickly throughout much of south-central Alaska during the earliest Holocene. Ager (1983) inferred that the trees were restricted to interfluves or warm, well-drained upland sites but that the regional vegetation was predominantly a Betula-Salix shrub tundra.

The above records also indicate that Picea (probably $P$. glauca) arrived in south-central Alaska at least 1000 years after Populus, Picea glauca macrofossils from Tangle Lakes, which today is ca. $25 \mathrm{~km}$ beyond treeline, are dated to 9100 $\mathrm{BP}$ and document an extension of Picea treeline during the early Holocene (Schweger, 1981). Picea was also present in the Copper River lowlands by $9000 \mathrm{BP}$, but did not arrive in the central Kenai Peninsula until ca. $8000 \mathrm{BP}$ and at Eightmile Lake until ca. 7500 BP (Ager, 1983). The early coniferous forests, dominated by $P$. glauca, were probably restricted to warm, well-drained low and mid-elevation sites. The forest composition changed during the middle Holocene to include large numbers of $P$. mariana, and the landscape cover of forests probably became more extensive at this time. The shift in Picea dominance almost certainly reflects a regional increase in cool, moist, nutrient-poor soils.

\section{THE POPULUS FORESTS OF ALASKA}

The period 9000 to $11,000 \mathrm{BP}$ has been inferred to be a time of maximum summer warmth in northern Alaska (Brubaker et al., 1983; Anderson et al., 1988). This conclusion is based on expanded populations of Populus (most likely $P$. balsamifera), other plants (e.g., Myrica, Typha latifolia), and animals (e.g., McCulloch and Hopkins, 1966; Edwards and Brubaker, 1986; Anderson, 1988; Anderson et al., 1988). Anderson et al. (1988) suggested that for the southern flanks of the Brooks Range, Populus populations were restricted to gallery forests and nearby south-facing hillslopes but were absent at mid- to high elevations. However, Ager (1983) and Hu et al. (1993) postulated that rather extensive Populus-Salix forests characterized large areas of lowland Alaska at this time.

Because the pollen spectra from the Populus period lack modern analogs (Anderson et al., 1989), vegetation reconstructions are particularly difficult. Consequently, Anderson and Brubaker (in press) have suggested that Populus pollen data should only be interpreted as a simple presence or absence of the trees within the region. This approach, however, may be too simplistic. Large variations in Populus percentages (from trace amounts to greater than $40 \%$ ) exist in the fossil records, suggesting significant variation in the landscape. The possibility of regional differences in the abundance of ancient Populus populations is also suggested by the range of interpretations of the Populus pollen records (i.e., relatively abundant forest $v s$. restricted interfluvial populations). If regional patterns in Populus occurred, some spatial coherency would be expected if the fossil pollen data were mapped.

Standard isopoll maps are difficult to interpret because of the large variation in pollen percentages (Anderson and Brubaker, in press). However, an interesting pattern emerges when the pollen data are summarized by ranking Populus percentages on a scale of 0 to 4 and the sites are classified by elevation (Fig. 5 ; Table I). We interpret rank 0 ( $0 \%$ Populus pollen) to indicate absence or extreme scarcity of trees in the catchment, with higher rankings reflecting increasing importance of Populus trees in the local and regional landscapes. 


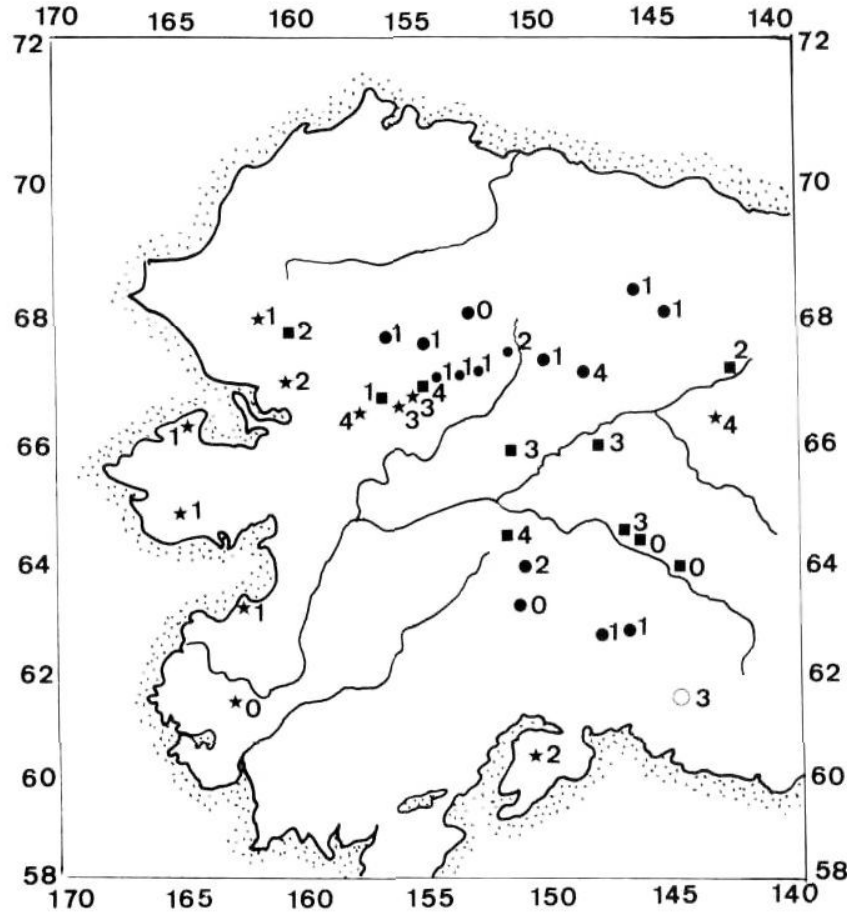

FIGURE 5. Map of lacustrine pollen records indicating Populus rank and elevation. The key to the Populus ranks is: $0=$ absent, $1=$ trace to $5 \%, 3=5$ to $10 \%, 4>15 \%$. The key to elevation classes is: $\star=0-200 \mathrm{~m}, \boldsymbol{\square}=200-400 \mathrm{~m}, \bigcirc=400-600 \mathrm{~m}, \boldsymbol{\theta}=600 \mathrm{~m}$.

Carte des inventaires polliniques lacustres de Populus illustrant les pourcentages et les altitudes. Pourcentages: $0=$ absent, $1=$ trace à $5 \%, 3=5$ à $10 \%, 4>15 \%$. Classes d'altitude: $\star=0-200 \mathrm{~m}, \mathbf{c}=$ $200-400 \mathrm{~m}, \mathrm{O}=400-600 \mathrm{~m}, 600 \mathrm{~m}$.

Ranks reflect the highest percentage recorded at a site during the Populus period. Sites are referred to as low to midelevation $(<400 \mathrm{~m})$ and high elevation $(>400 \mathrm{~m})$.

All sites except Wonder, Birch, George, Tungak, and Chandler Lakes have at least minor amounts of Populus pollen during the Populus interval. High elevation sites tend to have lowest and low elevations highest percentages. The major patterns in the Populus data suggest that extensive populations occurred in the lowlands with isolated stands or clones restricted to upland settings. These data also suggest that a broadleaf forest may have covered much of what is now Picea mariana- $P$. glauca forest.

\section{THE PICEA FORESTS OF ALASKA}

Holocene pollen records from lakes in the forest and forest-tundra ecotone of northern Alaska indicate the presence of open $P$. glauca forests in northeastern and northcentral Alaska 9500 to $8000 \mathrm{BP}$, a decline in $P$. glauca populations between 8000 and $7000 \mathrm{BP}$, and a rapid establishment at ca. $6000 \mathrm{BP}$ of $P$. mariana- $P$. glauca forests across most of the region. The modern composition and distribution of boreal forest was in place 5000 to $4000 \mathrm{BP}$ (Anderson and Brubaker, in press). There is insufficient evidence to suggest that Picea populations extended beyond latitudinal or altitudinal treelines during the postglacial.
Pollen records in south-central Alaska are too sparse and poorly dated to examine Picea history with similar detail as for the north. Nonetheless, these records can be used to infer general Holocene migrational patterns of Picea; insufficient sites exist to document altitudinal fluctuations in treeline. As in the north, postglacial Picea populations first appeared in the east and then spread westward. For example, Picea percentages increased prior to $9000 \mathrm{BP}$ at Ten Mile, Tangle, and 70 Mile Lakes, but did not rise until ca. 7500 BP at Eightmile Lake. Unfortunately, the poor chronological control for Wonder Lake and the lack of data from the upper and middle Kuskokwim drainage (Fig. 1) do not permit the dating of its spread farther to the west or southwest. However, Ager (1983) inferred that Picea populations probably were present in the Yukon-Kuskokwim delta by $5500 \mathrm{BP}$, based on low Picea pollen percentages at Tungak and Puyuk Lakes (Fig. 1). Picea populations also moved rapidly southward in southcentral Alaska during the early Holocene, establishing in the central Kenai Peninsula by 8000 BP.

The similarity in the arrival times of Picea in south-central and northern Alaska (i.e., ca. $9000 \mathrm{BP}$ in the eastern portion of the state and ca. $5000 \mathrm{BP}$ in western Alaska) suggests that the northern and southern coniferous forests did not differ significantly as regards an east-to-west migration across the state. Yet the forest histories of south-central and northern Alaska do vary. The southern pollen diagrams, with the exception of a discontinuous record from Tangle Lakes, do not imply a fluctuation in the size of early Holocene Picea populations, as found in northern Alaska. Picea percentages in the southern sites (except Wonder Lake) increase sharply to greater than $20 \%$ in the early Holocene and remain high throughout the remainder of the record, suggesting that population densities have been similar to today during most of the Holocene. In northern Alaska, the reduction in P. glaucadominated forests has been attributed to cooling of middle Holocene climates (Anderson and Brubaker, 1993; Hu et al., 1993). The early Holocene Picea forests of south-central Alaska (presumed to be $P$. glauca based on extrapolation of the Ten Mile and Wonder lakes data) evidently were unaffected by this climatic change. If tree density was high, as suggested by the high percentages of Picea pollen, the forests could have created their own microenvironment, which is less susceptible to decreasing temperatures, thereby permitting the continuation of well developed forests throughout the Holocene. The only clear evidence of a fluctuation in Picea populations is from Tangle Lakes, where $P$. glauca macrofossils indicate the tree's presence by $9100 \mathrm{BP}$, with an apparent decline in the population, as indicated by low Picea pollen percentages in a 4700 year core, some time after 9100 BP. Because Tangle Lakes is at a higher elevation, it is possible that the vegetation during the early Holocene was a forest-tundra with a relatively sparse tree cover. In this situation, a decline in Picea near Tangle Lakes would be conceivable, even though lower elevation populations remained unchanged.

\section{CONCLUSIONS}

Available data from south-central Alaska clearly are too meager to evaluate the role of climate in the development of 
the southern boreal forest. Consequently, we lack sufficient data to postulate how this forest may respond to global warming and whether it will respond differently than the northern boreal forest. The above data, however, hint at possible variations in the forest development, even though the northern and southern Alaskan forests share the same species composition. A dense grid of well-dated fossil records must be collected before the preliminary vegetation history presented here can be evaluated and any "working climatic hypotheses" can be formulated. As illustrated by the Wonder Lake core, reliable dating is often a problem in Alaskan lakes, which typically have low organic content and lack plant macrofossils, and therefore require large bulk sediment samples for dating. Steps must be taken to improve dating control by less reliance on bulk dates (e.g., greater use of terrestrial macrofossils and development of techniques to concentrate sufficiently clean samples of pollen for radiocarbon assays). Other problems must also be addressed in order to understand the history of climate-vegetation interactions in southcentral Alaska. One is the apparent over-representation of certain pollen taxa, in particular Picea, at forest-tundra sites. Long distance dispersal of low elevation taxa is not a significant factor for the interpretation of pollen records from the Brooks Range, but the greater topographic variability of the Alaska Range may result in greater transport of valley taxa to higher elevations making the interpretation of local vegetation more difficult than in northern Alaska. A detailed study of altitudinal variation in modern samples is vital to help interpret the fossil records. In addition, Picea pollen must be differentiated in both modern and fossil samples to compare the histories of these species with that described for northern Alaska. Finally, multiple proxy data sets (e.g., pollen, macrofossil, sediment geochemistry, diatoms) will be especially important to describe the development of the modern boreal forest of south-central Alaska and its relationships to late Quaternary climatic changes.

\section{ACKNOWLEDGEMENTS}

This research was supported by the National Science Foundation (ATMS-8915415) and the Far Eastern Branch of the Russian Academy of Science. We especially appreciate the help of AI Werner who shared unpublished data and ideas with us about Wonder Lake. We also would like to thank V. Davydov, L. Kotova, I. Gushina, M. Miller, A. Polujan, and T. Wheeler for their help in the field. The National Park Service and the Bureau of Land Management kindly granted permission to core the lakes. We also thank T. Anderson and an unnamed reviewer for comments on an earlier version of the manuscript and P. Heiser and L. Carlson for help in manuscript preparation.

\section{REFERENCES}

Ager, T.A., 1975. Late Quaternary Environmental History of the Tanana Valley, Alaska. Ohio State University Institute for Polar Studies Report 54, Columbus.

1982. Vegetational history of western Alaska during the Wisconsinan glacial interval and the Holocene, p.75-94. In D. M. Hopkins, J.V. Matthews Jr., C.E. Schweger and S.B. Young, eds., Paleoecology of Beringia. Academic Press, New York, 489 p.
- 1983. Holocene vegetational history of Alaska, p. 128-141. In H.E. Wright, Jr. ed., Late Quaternary Environments of the United States, Volume 2, The Holocene. University of Minnesota Press, Minneapolis, $277 p$.

Ager, T.A. and Brubaker, L.B., 1985. Quaternary palynology and vegetational history of Alaska, p. 353-384. In V.M. Bryant, Jr. and R.G. Holloway, ed., Pollen Records of Late-Quaternary North American Sediments. American Association of Stratigraphic Palynologists, Dallas, $423 \mathrm{p}$.

Ager, T.A. and Sims, J.D., 1981. Holocene pollen and sediment records from the Tangle Lakes area, central Alaska. Palynology, 5: 85-98.

Anderson, P.M., 1985. Late Quaternary vegetational change in the Kotzebue Sound area, northwestern Alaska. Quaternary Research, 24: 307-321.

1988. Late Quaternary pollen records from the Kobuk and Noatak River drainages, northwestern Alaska. Quaternary Research, 29: 263-276.

Anderson, P.M. and Brubaker, L.B., 1986. Modern pollen assemblages from northern Alaska. Review of Palaeobotany and Palynology, 46: 273-291.

1993. Holocene vegetation and climate histories of Alaska, p. 386-400. In H. Wright Jr., J. Kutzbach, T. Webb III, W. Ruddiman, F. Street-Perrott and P. Bartlein, eds., Global Climates since the Last Glacial Maximum. University of Minnesota Press, Minneapolis, $569 \mathrm{p}$.

_- In press. Late Quaternary vegetation history of Alaska: A mapped summary of pollen data. Quaternary Science Reviews.

Anderson, P.M., Reanier, R.E. and Brubaker, L.B., 1988. Late Quaternary vegetational history of the Black River region in northeastern Alaska. Canadian Journal of Earth Sciences, 25: 84-94.

1990. A 14,000-year pollen record from Sithylemenkat Lake, northcentral Alaska. Quaternary Research, 33: 400-404.

Anderson, P.M., Bartlein, P.J., Brubaker, L.B., Gajewski, K. and Ritchie, J.C., 1989. Modern analogues of late-Quaternary pollen spectra from the western interior of North America. Journal of Biogeography, 16: 573-596.

Barnosky, C.W., Anderson, P.M. and Bartlein, P.J., 1987. The northwestern U.S. during deglaciation: vegetational history and paleoclimatic implications, p. 289-321. In W.F. Ruddiman and H.E. Wright, Jr. eds., North America and Adjacent Oceans during the Last Deglaciation. Geological Society of America, Boulder, $501 \mathrm{p}$.

Brubaker, L.B., Graumlich, L.J. and Anderson, P.M., 1987. An evaluation of statistical techniques for discriminating Picea glauca from Picea mariana pollen in northern Alaska. Canadian Journal of Botany, 63: 616-626.

Brubaker, L.B., Garfinkel, H.L. and Edwards, M.E., 1983. A late Wisconsin and Holocene vegetation history from the central Brooks Range: Implications for Alaskan paleoecology. Quaternary Research, 20: 194-214.

Cwynar, L.C., Burden, E. and McAndrews, J.H., 1979. An inexpensive sieving method for concentrating pollen and spores from fine-grained sediments. Canadian Journal of Earth Science, 16: 1115-1120.

Edwards, M.E. and Brubaker, L.B., 1986. Late-Quaternary environmental history of the Fishhook Bend area, Porcupine River, Alaska. Canadian Journal of Earth Sciences, 23: 1765-1773.

Edwards, M.E., Anderson, P.M., Garfinkel, H.L. and Brubaker, L.B., 1985. Late Wisconsin and Holocene vegetational history of the upper Koyukuk region, Brooks Range, Alaska. Canadian Journal of Botany, 63: 616-626.

Emanuel, W.R., Shugart, H.H. and Stevenson, M.P., 1985. Climatic change and the broad-scale distribution of terrestrial ecosystem complexes. Climatic Change, $7: 29-43$.

Faegri, K. and Iversen, J., 1989. Textbook of Pollen Analysis. IV edition. John Wiley and Sons, New York, $328 \mathrm{p}$.

Gaudreau, D.C. and Webb, T., III, 1985. Late-Quaternary pollen stratigraphy and isochrone maps for the northeastern United States, p. 245-280. In V.M. Bryant, Jr. and R.G. Holloway, ed., Pollen Records of Late-Quaternary North American Sediments. American Association of Stratigraphic Palynologists, Dallas, $423 \mathrm{p}$.

Grichuk, V.P. and Zaklinskaya, E.D., 1948. Analysis of Fossil Pollen and Spores and Its Application to Paleogeography. Geographical Publications, Moscow. 
Hu, F.S., Brubaker, L.B. and Anderson, P.M., 1993. A 12000-yr record of vegetation change and soil development from Wien Lake, central Alaska. Canadian Journal of Botany, 71: 1133-1142.

Lamb, H,F. and Edwards, M.E., 1988. The Arctic, p. 519-555. In B. Huntley and T. Webb III, eds., Vegetation History. Kluwer Academic Publishers Dordrecht, $803 \mathrm{p}$.

Livingstone, D.A., 1955. Some pollen profiles from arctic Alaska. Ecology, 36 587-600.

MacDonald, G.M., Beukens, R.P. and Kieser, W.E., 1991. Radiocarbon dating of limnic sediments: A comparative analysis and discussion. Ecology, 73: 1150-1155.

McCulloch, D.S. and Hopkins, D.M., 1966. Evidence for an early Recent warm interval in northwestern Alaska. Geological Society of America Bulletin, 77: 11089-1108.

Pastor, J. and Post, W.M., 1988. Response of northern forests to $\mathrm{CO}_{2}$-induced climate change. Nature, 334: 55-58.

Péwé, T.L., 1975. Quaternary Geology of Alaska. U.S. Geological Survey Professional Paper 835, $145 \mathrm{p}$.

Péwé, T.L. and Reger, R.D., eds., 1983. Richardson and Glenn Highways, Alaska: A Guidebook to Permafrost and Quaternary Geology. Alaska Division of Geological and Geophysical Surveys, Anchorage, 263 p.

Reed, J.C., Jr., 1961. Geology of the Mt. McKinley quadrangle, Alaska. U.S Geological Survey Bulletin 1108-A, 36 p.

Schlesinger, M.E. and Mitchell, J.F.B., 1987. Climate model calculations of the equilibrium climate response to increased carbon dioxide. Review of Geophysics, 25: 760-798.
Schweger, C.E., 1981. Chronology of late glacial events form the Tangle Lakes, Alaska Range, Alaska. Arctic Anthropology, 18: 97-101.

Stockmarr, J., 1972. Tablets with spores used in absolute pollen analysis. Pollen et Spores, 13: 615-621.

Ten Brink, N.W. and Waythomas, C.F., 1985. Late Wisconsinan glacial chronology of the north-central Alaska Range: A regional synthesis and its implications for early human settlements. National Geographic Society Research Reports, 19: 15-32.

Viereck, L.A., Dyrness, C.T., Batten, A.R. and Wenzlick, K.J., 1992. The Alaska Vegetation Classification. United States Department of Agriculture, Forest Service, Pacific Northwest Research Station, Portland (OR), 278 p.

Werner, A., 1982. Glacial geology of the McKinley River area, Alaska with an evaluation of various relative age dating techniques. M.S. thesis, Southern Illinois University, Carbondale, $147 \mathrm{p}$.

- unpublished. Bathymetry and Stratigraphy of Wonder Lake, a Glacial Lake in Denali National Park and Preserve, Alaska, 23 p.

Werner, A. and J. Child., 1992. High Resolution Record of Late Wisconsin Climatic Events, Denali National Park and Preserve, Alaska. Unpublished Report to the National Park Service, 22 p.

Wright, H.E. Jr., Mann, D.H. and Glaser, P.H., 1984. Piston corers for peat and lake sediments. Ecology, 65: 657-659.

Wahrhaftig, C., 1958. Quaternary geology of the Nenana River valley and adjacent parts of the Alaska Range. U.S. Geological Survey Professional Paper 293-A, $60 \mathrm{p}$. 